DOI: $10.22559 /$ folklor.1007

folklor/edebiyat, cilt: 25 , sayı: $100,2019 / 4$

\title{
Sosyal Gösterim Modeli Üzerinden Bağrıyanık Ömer Adlı Romanı Okuma Denemesi
}

\author{
An Attempt to Read the Novel Named Bağrıyanık Ömer \\ Using Social Representation Model
}

Tülin Arseven*

$\ddot{O} \mathbf{z}$

İlhan Başgöz'ün (D.1923- Sivas) bilimsel araştırmaları üzerine akademisyen Serdar Öztürk kapsamlı ve dikkate değer bir çalışma yapmıştır. Araştırmacı Serdar Öztürk bu çalışmasında İlhan Başgöz'ün bilimsel çalışmalarına dair çok önemli saptamalarda bulunmuştur. Bunlardan biri de İlhan Başgöz'ün iletişim bilimi ile halkbilimi birleştirmiş olduğudur. Serdar Öztürk, İlhan Başgöz'ün halk hikâyelerini incelerken kullandığ1 yöntemin ana çatısını gösterimci ekolün argümanlarının oluşturduğunu öne sürer ve İlhan Başgöz'e göre "sözlü anlatım sosyal bir gösterimdir" saptamasında bulunur. Serdar Öztürk, hikâye anlatımının sosyal gösterim olduğu düşüncesinden ve bu çerçevede öne sürdüğü görüşlerden yola çıkarak İlhan Başgöz'ün sosyal gösterim anlayışını modelleştirir. Hikâye anlatıcısının uzak ve yakın toplumsal çevre ile dinleyici arasındaki iletişimini şematik bir çerçeveye oturtur. Bu şema ile Serdar Öztürk, İlhan Başgöz'ün hikâye inceleme tarzını açık ve anlaşılır hale getirir. "Sosyal Gösterim Modeli Üzerinden Bağrıyanık Ömer Adlı Romanı Okuma Denemesi” başlıklı bu çalışma da Serdar Öztürk tarafından oluşturulan şemayı temel alarak romanı incelemeyi amaçlamaktadır. Mahmut Yesari (1895-1945) tarafından yazılan bu romanın ilk basımı 1930 yılında yapılmıştır.

Prof. Dr., Akdeniz Üniversitesi Eğitim Fakültesi, tulinarseven@yahoo.com. ORCID ID: 0000-0002-2410-5662. 
Kahramanının bir çocuk olması bakımından edebiyatımızın ilkleri arasında sayılan bu roman, geleneksel ve modern anlatıyı birleştirmektedir. Bu çalışma, geleneksel anlatıyı incelemek üzere İlhan Başgöz tarafından uygulanan bir yöntemin modern bir anlatı metnine uygulaması şeklindedir. Başka bir ifade ile İlhan Başgöz'ün Serdar Öztürk tarafından "sosyal gösterim" olarak formüle edilen yönteminin romana uygulanmasıdır. Bu uygulama ile İlhan Başgöz'ün iletişim bilimi ile halkbilimi birleştiren yaklaşımının geleneksel olan ile modern olanı birleştiren, ancak sözlü değil yazılı kültürün ürünü olan bir metin üzerinde gerçekleştirilmesi amaçlanmaktadır. Böylece Bağrıyanık Ömer, edebî metin incelemeleri için yeni bir bakış açısıyla ve birden çok disiplini kapsayan bir model ile incelenmiş; ele alınan roman sosyal bir gösterim midir sorusuna yanıt aranmıştır.

Anahtar sözcükler: İlhan Başgöz, Serdar Öztürk, sosyal gösterim, hikâye

\section{Abstract}

Academic Serdar Öztürk made a remarkable and extensive study on scientific researches of İlhan Başgöz (Birth 1923 - Sivas). Researcher Serdar Öztürk made very important detections about scientific studies of İlhan Başgöz in this study. One of these detections is that İlhan Başgöz united communication science with folklore. Serdar Öztürk states that the main skeleton of the method İlhan Baştürk used for studying folktales consists of arguments of representative school and he determines that according to İlhan Başgöz oral narrative is a social representation. Serdar Öztürk, based on the idea of telling a story being a social representation and opinions he stated in this context, models İlhan Başgöz's perception of social representation. He creates a diagram of communication of the narrator between near and distant environment and audience. With this diagram, Serdar Öztürk makes İlhan Başgöz's story examination style clear and understandable. This study named "An Attempt to Read the Novel Named Bağrtyanık Ömer Using Social Representation Model" aims to examine the novel using the diagram created by Serdar Öztürk as the base. The first edition of this novel written by Mahmut Yesari (1895-1945) was made in 1930. This novel, which is considered as one of the firsts of our literature in terms of having a child as the protagonist, combines traditional and modern narrative. This study is in the form of applying a method applied by İlhan Başgöz to examine a traditional narrative to a modern narrative. In other words, it is the application of İlhan Başgöz's method formulated by Serdar Öztürk as "a social representation” to the novel. With this practice, İlhan Başgöz's approach that unites communication science and folklore is aimed to be carried out on a text that combines the traditional with the modern, but that is the product of written culture rather than oral. Thus, Bağrlyanık Ömer was examined with a new perspective for the study of literary texts and with a model covering multiple disciplines; the question of whether the novel is a social representation was sought.

Keywords: Illhan Başgöz, Serdar Öztürk, social representation, story 


\section{Giriş}

Bu makalenin temel dayanak noktası; İlhan Başgöz'ün (D. 1923- Gemerek/Sivas) halkbilim alanındaki çalışmalarını iletişim biliminin verileri çerçevesinde nasıl ele aldığını inceleyen Serdar Öztürk’ün“İletişim Bilimi ile Halkbilimi Buluşturan Bir Bilim İnsanı: İlhan Başgöz” başlıklı yazısında öne sürdüğü görüşler ve vardığı sonuçlardır. Serdar Öztürk sözü edilen makalesinde İlhan Başgöz’ün bilimsel çalışmalarının kavramsal çerçevesini bir ölçüde iletişim biliminin kuramları üzerinden ele aldığını saptadığını belirtir ve İlhan Başgöz’ün halk hikâyelerinin nasıl incelenmesi gerektiği üzerindeki görüşlerini irdeler. Serdar Öztürk, İlhan Başgöz'ün halkbilim ve iletişim biliminin önde gelen kuramcılarından hareketle bir model geliştirdiğini söyler (Öztürk, 2006: s.48). Serdar Öztürk'ün İlhan Başgöz'ün iletişim modeline dair oluşturduğu şema aşağıda verilmiştir (Öztürk, 2006: s.50):

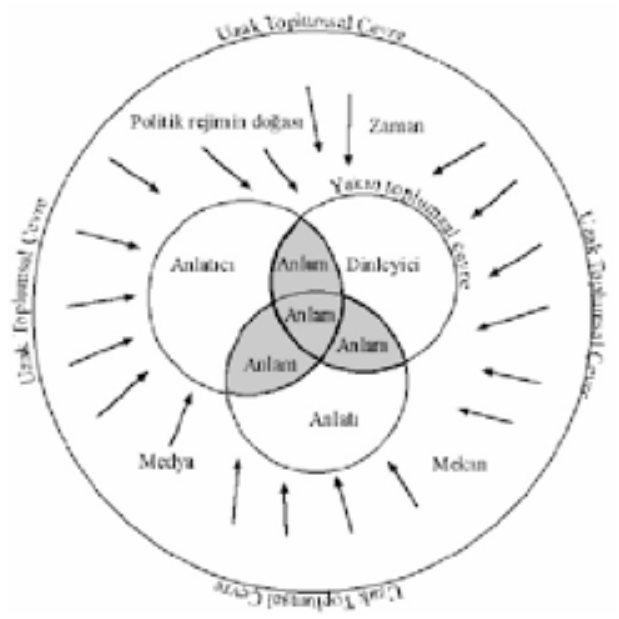

Şekil 1: Serdar Öztürk tarafından oluşturulan İlhan Başgöz’ün Sosyal Gösterim Modeli

"Sosyal Gösterim Modeli Üzerinden Bağrıyanık Ömer Adlı Romanı Okuma Denemesi” başlıklı bu çalışmanın çıkış noktasında romanın da tıpkı halk hikâyesi gibi bir iletişim nesnesi olması, edebiyat araştırmalarında farklı disiplinlerin yaklaşımlarının edebî metinlere uygulanabilirliğinin tartışmaya açılması ve benzer araştırmalar için örnek oluşturma düşüncesi yatmaktadır. Bu çalışmada alışılagelmiş roman çözümleme yöntemlerinin bir hayli dışında bir tutum izlendiği açıktır. Serdar Özürk, İlhan Başgöz'ün halk hikâyesi inceleme yöntemini modelleştirirken “Başgöz'ün Temel Anlayışı: Sözlü Anlatım 'Sosyal Gösterimdir'”, (Öztürk, 2006: s. 48) demektedir. Serdar Öztürk, yukarıda gösterilen modelde geri beslemenin olmad1-ğına da dikkat çekmektedir (Öztürk, 2006: s.51). Geri beslemenin olmayışı tek yönlü bir ileti-şimi düşündürmektedir. $\mathrm{Bu}$ ise, yazılı bir anlatı olarak romanın sosyal gösterim kavramı etra-fında ele alınabilmesini kolaylaştırmaktadır. Burada incelenmek üzere seçilen romanın halk hikâyeciliğinin temel yapı unsurlarını içerme, geleneksel olan ile modern anlatıyı birleştirme özelliği de önem taşımaktadır. Bağrıyanık Ömer adlı roman, bu çalışmada sosyal psikolojinin sosyal gösterim/temsil (a social representation) şeklinde kavramlaştırdığı bir bakış açısıy- 
la, edebî metnin tek taraflı (yazardan okura/ sanatçıdan topluma) bir iletişim örneği olduğu varsayımından hareketle ve aslında daha önce sözlü kültüre ait anlatılar üzerinde yapılmış örnekleri olan bir yöntem ile incelenmiştir. Sosyal psikoloji, halkbilim ve iletişim biliminin bilgi evrenine başvurularak yapılan bu çalışmanın temeli, İlhan Başgöz'ün de çalışmalarında üzerinde durduğu anlatı metninin toplumsal bağlarından kopuk olmayan, duruma/zamana/ mekâna/çağa göre değişen yapısı üzerine uygulanan bir yöntemin aslında yazılı edebiyatın ürünü olan, toplumsal yapının yansıması olmakla birlikte değişmez bir metne uygulamanın verdiği sonuçları görmek üzerinedir. Ayrıca sözlü kültür ve edebiyat ürünlerinin incelenmesinde kullanılan bir yöntemin yazılı edebiyat ürünlerine uygulamasının ne ölçüde olası olduğunu da saptamaktır. İncelenmek üzere seçilen metin (yazılı bir metin olması nedeniyle artık değişmez ve olduğu gibi gelecek kuşaklara aktarılacağı bilgisi göz önüne alınarak), İlhan Başgöz'ün inceleme yönteminden hareketle Serdar Öztürk'ün geliştirdiği model ve sosyal gösterim kavramı odağında ele alınmıştır. Bu çalışma edebiyat araştırmalarında yeni bir bakış açısı ve yöntem tartışmasını da dikkatlere sunmaktadır.

\section{Sosyal gösterimin ögeleri ve Bă̆rıyanık Ömer adlı romanın incelenmesi}

Bu bölümde ilk olarak sosyal gösterim kavramının ne olduğu üzerinde durulacaktır. Ardından Bă̆rıyanık Ömer adlı roman, sosyal gösterimin ana ilkeleri üzerinden incelenecektir.

Sosyal gösterim teorisi sosyal yapının anlaşılmasında en önemli adım olarak anonim gerçeklerin analizini gerekli görür (Moscovici'den akt. Öner, 2002, s.30). Temsiller, bir grubun ya da onun imajlarının değişim içine girdiği sırada ortaya çıkar veya değişirler. Kriz zamanlarında insanlar konuşmaya daha çok istekli olur, imajlar ve ifadeler daha canlıdır. Toplumsal hatıralar daha hareketli, davranış daha çok kontrolsüzdür. Kişiler gitgide zihni karıştıran ve tanıdık gelmeyen dünyayı tanıma arzusu ile harekete geçerler. Özel ve toplumsal dünyalar arasındaki bölünmelerin bulanıklaşması ile sosyal içerikli yeniden yapılanmalar daha çıplak, daha az süslenmiş bir şekilde gözükür. Dolayısı ile sosyal temsillerin başlangıcı yeni bir bilimsel katkı ya da gündemdeki bir olayla başlar. Ancak bu tip olayların sadece ortaya çıkmaları sosyal temsillerin oluşumu için yeterli değildir. Bunların ilginç ve önemli bir şekilde ortaya çıkmaları gerekmektedir (Moscovici'den akt. Öner, 2002: 30,31). Modern üretim koşullarının hâkim olduğu toplumların tüm yaşamı gösterilenlerin uçsuz bucaksız birikimi olarak görünmektedir (Debord, 2006: s.35) ve yaşamın her bir yönünden kopmuş olan imajlar, bu yaşamın birliğini yeniden kurmanın artık mümkün olmadığı ortak bir akışta kaynaşırlar. Kısmi olarak göz önüne alınan gerçeklik, ayrı bir sahte dünya olarak, salt seyrin nesnesi olarak, kendi genel birliğinde sergilenir. Dünyasal imajlardaki uzmanlaşma, yalancının kendine yalan söyledi-ği özerkleşmiş imaj âleminde, kendini tamamlanmış bulur. Genel anlamda gösteri, yaşamın somut ters yüz edilişi olarak, canlı olmayanın özerk devinimidir (Debord, 2006: s. 35, 36). Gösteri kendini hem bizzat toplum olarak, hem toplumun bir parçası olarak ve hem de bir birleştirme aracı olarak sunar ve toplumun bir parçası olarak, özellikle, bütün bakış ve bilinçleri bir araya getiren sektördür. Gösteri bir imajlar toplamı değil, kişiler arasında var olan ve imajların dolayımından geçen bir toplumsal ilişkidir (Debord, 2006: s.36). Toplumsal bir ilişkiden söz edildiğinde bunun iletişim boyutu da gündeme gelmektedir. Roman yazarı Dian-ne Doubtfire'a göre insanın en büyük ihtiyaçlarından biri benzerleriyle iletişim kurabilmek, anlamak ve anlaşılmaktır (Doubtfire, 1999: s.7). Bireylerin iletişimi kadar kitlelerin iletişimi 
ve araçları da önemli bir konudur. Denis McQuail ve Sven Windhal'a göre kitle iletişim araçlarının birincil amacı çoğu kez ne belirli bir enformasyon iletmek ne de kamuoyunu kültür, inanç ve değer yargısında birleştirmektir. Amaç, çok basit olarak izleyicinin görsel veya işitsel olarak ilgisini çekmek ve bunu sürdürmektir (McQuail ve Windhal, 1997: s.70). Gösterim olarak iletişimin başarısı edinilen toplam ilginin göreceli payı ile ölçülmektedir (McQuail ve Windhal, 1997: s.71). McLuhan'a göre ileti, iletişim aracının kendisidir ve bir kültürün ak-tarım tarzı o kültüre etkide bulunarak onu dönüştürmektedir (Alemdar ve Kaya,1983: s. 13). Popüler kültür satın alınan, halk kültürü ise imal edilendir ve halk kültürü iş ve dinlemenin birbirini tamamlayıcı, birbirine zıt olmadığı, bitişik olduğu dönemin kültürüdür (Alemdar ve Erdoğan, 1994: s.120). Halk kültürünün oluşum sürecinde üretim ve aktarım birliği vurgusu önemlidir. Halk verimlerinin en önemli özelliklerinden biri kültür aktarımı, kültür taşıyıcılığı işlevine sahip olmalarıdır. Burada incelenmek üzere seçilen roman da bir anlamda kültür taşı-yıcılığı görevi görmektedir. Sibel A. Arkonaç, "Moscovici sosyal temsillerin, kişilerin birbiri ile olan etkileşimleri ile sürekli inşa edildiğini savunur. Sosyal temsilleri oluşturan nesneler hemen hemen sinırsı bir şekilde cemaatin, bir topluluğun paylaştı̆̆l ikirler, düşünceler, imaj-lar ve bilgilerdir.” (Arkonaç, 2001, s.103) demektedir. Bu çalışmada incelenmek üzere seçi-len Bă̆rıyanık Ömer adlı romanda da Ömer'in hikâyesi yıllar içinde yeniden inşa edilmiş, anlatı beraberinde birtakım ritüellerin (yoldan geçerken başını eğme, düğün sırasında gelin ve damadın yaptığı uygulamalar, vb) oluşumunu sağlamıştır. Băgrıyanık Ömer adlı roman da bu dört unsur üzerinden ve İlhan Başgöz'ün şematize edilen yöntemi ile incelenmiştir. Serdar Öztürk, bir sözlü anlatımda/ gösterimde anlamı oluşturan bütün unsurları dört başlık altında ele almaktadır. Buna göre sosyalıg̈̈șterimin unsurları şunlardır (Öztürk, 2006: s. 51-55):

\section{Anlatı (Geleneksel Tür )}

\section{Yakın Toplumsal Çevre: Dinleyici}

4. Uzak Toplumsal Çevre: Politik rejim, medya, mekân, zaman

Bă̆rıyanık Ömer adlı romanı anlatıcı, anlatı, yakın ve uzak toplumsal çevre açısından ele almadan önce eserin içeriği hakkında kısaca bilgi vermek uygun olacaktır. Bağrıyanık Ömer, parçalanmış bir ailenin ve bu aile içindeki küçük bir çocuğun trajik yaşamının romanıdır. Anne, baba ve tek çocukları olan Ömer'den oluşan bu çekirdek ailede anne-baba arasında şiddetli bir geçimsizlik söz konusudur. Birbirlerine duydukları sevginin tükendiği, saygının kalmadığı bu çiftin neredeyse tek ortak noktası çocukları Ömer'e duydukları sevgidir. Eşinden ayrılmak ve Ömer'e tek başına sahip olmak isteyen babanın türlü entrikası romanda olaylara yön veren ana çıkış noktasını oluşturur. Uzun süren bir boşanma sürecinin ardından ayrılan çift, kendilerine yeni hayatlar kurup mutlu olmanın yollarını ararlar. Ancak bu arada Ömer, önce anne ve babasının kavgasının arasında, sonra da anne ve babasının kurduğu yeni yuvaların dışında yalnız, kimsesiz, ilgisiz ve bakımsız hatta aç ve susuz kalır. İçinde bulunduğu duruma daha fazla dayanamayan Ömer, yaşından (6 yaşındadır) beklenilmeyecek bir tavır ile anne babasına ve yaşama küser, intihar eder. Henüz oyun çağında olan, küçük bir çocuğun yaşadıkları üzücüdür. Ömer ve anne babasının durumu, pek çok parçalanmış ailenin yaşadıklarından farklı değildir. Bu nedenle Ömer ve ailesinin yaşadıkları aslında toplum içinde örnekleri sıkça görülen, aile içi psikolojik ve fiziksel şiddetin birer yansımasıdır. Roman, 
anne babanın bencilliğinin çocuklarına nasıl zarar verdiğini göstermesi noktasında önemlidir. Ömer'in kısacık yaşamı ebeveynler ile topluma çok değerli iletiler verirken, Bă̆rıyanık Ömer adlı roman da okurda bir sosyal gösterim etkisi yaratmaktadır. Sosyal gösterimin unsurları açısından roman incelendiğinde ulaşılan bilgilere aşağıda sırasıyla yer verilmiştir.

\section{Anlatıcı}

Sosyal gösterimin ilk olarak üzerinde durulması gereken ögesi anlatıcıdır. Serdar Öztürk’e göre İlhan Başgöz, halk hikâyelerini incelerken anlatıcıyı dışarıda bırakmaz. Anlatının canlılığını, dinamizmini sağlayan, hikâyenin kurgusunu seyirci/ dinleyici grubunun özelliklerine tepkilerine göre değiştiren anlatıcı son derece önemlidir (Öztürk, 2006: s.51). İlhan Başgöz de anlatıcı konusunda şöyle der:
Anlatıcı gösterimde, hemen her zaman başka insanları anlatır, başka çeveteri an- latır, onların yerine konuşı̇mlattığı hikâye başkalarının maceralarından oluşur Fakat buanlatıcı orada, öz kişiliğini saklayarak, sahnede rol yapan, başkalarının karakterine bürünen, temsil ettiği karakterleri taklit eden bir oyundkğildir. Ís- tediği kadar kendisini hikâye karakteri ile özdeşleştirsin, istediği kadar kendisini hikâyedeki maceraların içinde görsün, o gene de hikâye anlatıcıdır ve bu karakte- rinden kopmaz. (Başgöz, 1998: s.100).

Elbette İlhan Başgöz'ün de Serdar Öztürk'ün de sözünü ettiği anlatıcı, sözlü edebiyat ürününün anlatıcısı yani anlatıyı dinleyici kitlesi önünde anlatan kişidir. Burada ise yazılı bir metnin anlatıcısı, sosyal gösterim kavramı etrafında ele alınmıştır.

Bağrıyanık Ömer adlı romanın en önemli ve dikkat çeken yönü, anlatıcısıdır. Aslında romanda iki ayrı anlatıcı göze çarpar. Çünkü romanını yazar; iç içe geçmiş, biri küçük ve yarım kalmış, diğeri büyük ve tamamlanmış iki parça halinde kurgulamıştır. Yarım kalan ilk hikâye, kendinden sonra gelen bölümün serimi şeklindedir ve romanı oluşturan asıl bölümü kapsar. Yarım bırakılan bu ilk bölümde anlatıcı, aynı zamanda hikâyenin kahramanıdır ve kim olduğu, ne iş yaptığg, Ömer'in hazin hikâyesinin anlatıldığı yere neden geldiği belli değildir, romanın herhangi bir yerinde de bu soruların yanıtı verilmez. Bu giriş bölümünde anlatıcı, sadece Ömer'in hazin hikâyesinin anlatımını sağlamaya hizmet eder. Bu iç içe geçmiş iki ana parçada birbirinden bağımsız farklı anlatıcı görülür. Her iki anlatıcı da romanın ilk başında ve ilk hikâye parçasında okurun karşısına çıkarılır. Roman,

Şoseden gidersek, gün kararmadan kasabaya varamayacaktır. Her adımda ayaklarımız kayarak fundalara, dikenli, sert yabanî otlara tutunmaktan avuçlarımız kanaya kanaya tırmandı̆̆ımız Sazlıtepe'de bir ăgaç altı arıyordum.

(...)

-Ă̆aç filân yok... Bu ne iş böyle?

Yoldaşım, bir ihtiyar köylüydü:

-Sazlıtepe, burası, dedi. Ağaç değil, ot bitmez, çimen yeşermez...

-Bu sazlar sulak yerlerde yetişir... Dağ başında görmemiştim.

-Haklısın ăga ... Bura zamanılan sulak yermis...

-Öyle ise, aşă̆ıdaki ova da göldü! 
-Onu bilmem! Bu taraflarda kime sorsan, sana böyle der.

-Sazlıtepe 'yi su bastı̆̆ını sen gördün mü?

-Ne ben, ne babam, ne dedem, ne de dedemin dedesi görmüş! Eski bir masaldır, kulaktan kulağa duymuşuzdur. Kara taşlı dağlar üstünde havuzlar ve bu havuzlarda canlı balıklar olduğunu işitmiştim.

(...)” (Yesari, 2017: s.11)

sözleriyle başlar. Bu ilk bölümde bir yolcu ile ona k1lavuzluk eden ihtiyar bir köylünün bir kasabaya varmak üzere yaptıkları yolculuğun anlatımı söz konusudur. Bu bölümün anlatıcısı, yolcudur. Kasaba yolunda ilerlerken anlatıcı, kendisine kılavuzluk eden ihtiyara bir gidiş yolu önerisinde bulunduğunu, ancak yaşlı adamın bunu şiddetle reddettiğini söyler. İhtiyarın özellikle yolun daha kestirme görünen tarafından yürümeye karşı çıktığını belirtir. Bu sırada ihtiyar köylünün kendisine evli ya da boşanmış olup olmadığını sorduğunu söyler. Anlatıcı, ihtiyar adama bunu neden merak ettiğini sorduğunda ise yanıt için biraz beklemesi gerektiği cümlesi ile karşılaşır. İhtiyar adam, bu arada dört dörtlükten oluşan hüzünlü bir şark $1^{1}$ söylemeye başlar. Şarkının sözleri içinde "Sen ağlama, ben ă̆layayım/ Gene anam gelin olur" (Yesari, 2017: s.15) dizeleri dikkat çeker. Yol üzerinde anlatıcı ve ihtiyar adam, Söğütçük denilen bir yerde mola verirler. Burada suyu berrak bir pınar vardır. Bu sudan doyasıya içer-ler ve oturup dinlenmeye başlarlar. Bu sırada ihtiyar adam, anlatıcıya neden boşanmış olup olmadığını sorduğunu açıklamanın zamanının geldiğini belirtir ve söylediği türkünün (ihtiyar adam burada türkü sözcüğünü kullanır) Ömer'in destanı olduğunu belirtir ve şöyle der:

Ömer'in destanı... Bu havayı kim çıkarmış bilinmez... yalnız elden ele, dilden dile dolaşır. Destanın yazılısını köyde arasan belki ele geçirebilirsin. Hoş komşu köylerde de Ömer'in destanını bilirler ya... Anadolu'da şayet uzun boylu dolaşmışığın varsa rastlamışsındır. Bir çok köylerin adı Ömerli'dir... İşte bu destandan ötürü... (Yesari, 2017: s.17).

Böylece ihtiyar adam, Anadolu'nun birçok yerinde rastlanılan Ömerli yer adları için destana ve destanda anlatılan olaylara atfen verildiği bilgisini aktarır. Tek bir anlatının aynı adı taşıyan birçok yer için geçer olduğunun altını çizer. Bu noktada ihtiyar adam, bulundukları mekân ile ilgili olarak geçmiş ile yaşanılan gün arasındaki davranış değişimlerinden söz eder. Anlatıcı, ihtiyar adamın sözlerinden sonra Ömer'in destanını merak ettiğini belirtir. Ancak Ömer'in destanını öğrendiği kaynak, ona kılavuzluk eden ihtiyar adam değil bir başkasıdır. $\mathrm{Bu}$ bölümde romanda "Kasabada Ömer'in destanını aradım; aksakallı, masal külçesi hâline gelmiş bir ihtiyar, hem okudu hem anlattı:" (Yesari, 2017, s.:8) denilerek söz ikinci bir anlatıcıya emanet edilir. "Aksakallı, masal külçesi hâline gelmiş ihtiyar” tamlaması, hikâyeyi anlatan kişiye saygı duyma ve aynı zamanda anlatılanın gerçekliğine inandırma işlevi gör-mektedir. Anlatıcı, Ömer'in hikâyesini yolda kılavuzluk eden ihtiyar köylü yerine, kasabada yaşayan, masal dağarcı̆̆ı geniş, sözüne güvenilir bir başka ihtiyardan dinlediğini belirtir. Ak-sakallı ihtiyar, Ömer'in başından geçenleri anlatırken tıpkı bir halk hikâyecisi gibi davranır. Ömer'in destanının anlatımına,

-Yüzlerce yul evveldi. Geçtiğin ovada bir şehir kuruluydu. Şimdiki bu kurak, çatlak yaylalar vaktiyle bol, geniş gölgelerini salan ă̆açlar, fidanlar, bağlar, bahçeler, çimler, çiçeklerle süslü idi... Tütmeyen ocak, ekilmemiş bir karış toprak, sürülme- 
miş bir dilim tarla yoktuBağlar arasından irmaklar geçenbahçelede kaynaklar fişkırırçeşmeleden tatlı sulaakardı. (...) Işste bışehir, bir gecenin içindळattı, mahvolduBir gece baştan başa meraları, yaylaları, tarlaları, bahçelerỉbastı. A ̆̆llardaki hayvanları sular boğdu, götürdü. Tarlalarda ekinleri sular aldı götür-dü... Çatılar uçtu, bacalar yıkıldı... Taş, taş üstünde kalmadı... (Yesari, 2017: s.19)

sözleriyle başlar. “Taş, taş üstünde kalmadı...” ifadesi romanın ilk ana bölümünün de son cümlesidir. Bundan sonra kurguda ne ilk anlatıcı ne de aksakallı ihtiyar görünür. Romanın ikinci ana parçası ve Ömer'in başından geçenlerin anlatıldığı bölüm,

Bakır Efe, iç avlunun kapısını açarken, karısınadbă̆ır

-Emine, Ömer nerede?

Emine merdivenin başına gelmişti, parmă̆ını ă̆zına götürdü:

-Bă̆ırma, küçük uyuyor... (Yesari, 2017: s.2)

diyalogu ile okurun karşısına çıkar ve yazar artık bundan sonra sözünü; her şeyi bilen, gören, Tanrısal anlatıcıya bırakır. Anlatının bu bölümünde Ömer'in başından geçenler anlatılır. Ömer'in içinde bulunduğu duruma daha fazla katlanamayıp intihar etmesi ile olay örgüsü son bulur. Bundan sonra Ömer'in hikâyesinin anlatımından üç adet yıldız konularak ayrılmış iki küçük paragraf yer alır:

Derler ki, Ömer'in susuzlukdidin damă̆l; ana baba hasretinden bağrı yanarken,

elinde bir sögüt dalıyla kendisini boşluğa bırakıveliği Kızılpınar, o gece taştı...

Ve gene derler ki; Sögüttçük, Băgrıyanık Ömer'in, elinde sögüt dalıyla

kaybolduğu yerdir... (Yesari, 2017: s.134)

Bu iki paragraf aksakallı masal anlatıcısının -Yüzlerce yıl evveldi... (Yesari, 2017: s. 19) diye başlayan yukarıda da bir kısmı verilen, anlatının serimini tamamlayan, bütünleyen, kapanış sözleridir. Bağrıyanık Ömer, kurgusal anlamda hikâye, halk hikâyesi ve romanın üst üste binmiş hâlidir. İlk giriş hikâyesi ile Ömer'in başından geçenlerin anlatıldığı hikâyeyi, bir yaşlı hikâye anlatıcısı birleştirir. Böylece Ömer'in hikâyesi ile bir doğa parçasının durumu (kurak, sulak, vb. olması) ve bir yere ad verilmesi arasında bir ilişki de kurulmuş olur. Birinci tekil kişi ile kurulan ilk anlatıcı, anlatılanın inandırıcılığının sağlanmasında önemli bir görev üstlenmiştir. Roman, ilk bölüm verilmeden, sadece Bakır Efe ile Emine arasındaki diyalog ile başlamış olsaydı, Söğütçük ve Kızılpınar'a dair efsanelerden söz edilemeyecek, Ömer ile efsaneler ilişkilendirilemeyecek ve Ömer'in başından geçenler sadece kurmaca olarak kalacaktı. Romanın ilk bölümü ve bu bölümdeki anlatıcı, bir tür olarak efsanenin kendisine inanılmayı istemesi özelliğine bir vurgudur.

\section{Anlatı: Roman}

Bağrıyanık Ömer adlı eserde anlatı, romandır. Roman iki ana parçadan oluşur. İlk ve kısa parçada anlatıcı, ihtiyar bir köylü ile bir köy yolunda birlikte yürümektedir. Yolun belli bir noktasına geldiğinde ihtiyar adam, kılavuzluk ettiği anlatıcıya başından bir evlilik geçip geçmediğini sorar. Bu soru, anlatıcı tarafından şaşkınlıkla karşılanır ve beraberinde niçin sorulduğunu anlamaya yönelik yeni bir soru getirir. Ara düğüm ve merak unsuru oluşturan 
bu konuşmada, ihtiyar adamın yöneltildiği bu sorunun yanıtı hemen verilmez. İhtiyar adam, soruyu neden sorduğunu yol üzerinde bulunan Söğütçük denilen yere geldiklerinde açıklar. İhtiyar kılavuz, Söğütçük’e eskiden daha çok itibar edildiğini, evlilik çağındaki gençlere gelip burada bir sögüdün gölgesinde iki rekât namaz kılıp üç İhlâs bir Fatiha okuyup üç avuç su içmezlerse kimsenin kızını vermediğini, yeni gelinlerin de buraya getirilip yüzlerinin süslerinin burada yapıldığını, ellerine kınaların burada yakıldığını, gelin alayındaki çocukların davul zurna eşliğinde Ömer'in türküsünü söylediklerini anlatır. Dügüun yapılan zamanlar dışında Ömer'in türküsünü söylemenin uğursuzluk sayıldığını, şayet Ömer'in türküsünü söyleyen çocuk öksüz, yetim kalmış ise ona ses çıkarılmadığını söyler. Artık o düğün alaylarının unutulduğundan yakınan ihtiyar adam, değişmeyen bir âdet olduğundan da söz eder. Bu da her yeni gelin ve güveyin kasaba yolundan geçerlerken, Söğütçük görünüp de gözden kayboluncaya kadar ona arkalarını dönmemeleri, başından iki nikâh geçmiş olan kadın ve erkeklerin Söğütçük'e uğramamaları ve Kızılpınar'dan su içmemeleridir. Bu durumda olan kadın ve erkeklerin kasaba yolundan da başlarını eğerek ve Söğütçük'e bakmadan geçiyor olmalarıdır. Bahtsız insanlar ise buraya gelmekte ve sögütten kırk bir yaprak koparıp suya atmakta, böylece suyun onların dileklerini Allah'a götürdügüne inanmaktadırlar (Yesari, s.18). Görüleceği gibi romanın bu ilk bölümü, Söğütçük'e dair halk inanışlarının anlatımını içermektedir. Bu bölümde bu halk inanışları ve hatta düğünlere dair ritüellerle birlikte bunlara kaynak olan Ömer'in destanının da varlığından söz edilir. Ömer'in destanı, romanın Bağrıyanık Ömer (Hikâye) adlandırması ile verilen ikinci ana bölümünde anlatılır.

Bu bölümde Ömer'in başından geçenler anlatılır. Böylece roman, iç içe geçmiş iki kurgusal parçadan oluşmuş olur. İlk, büyük halkada anlatıcı ve yabancı bir adam yolda yürümektedirler. Burada zamanda kronolojik bir akış, mekânda ana menzile giden düz bir çizgi yani devamlılık vardır. Ömer'in hikâyesi bu yol üzerinde yolun belirli bir yerinde anlatılmaya başlanır ve belli bir yere (uçurum kenarı) gelince tamamlanır. Ömer'in hikâyesinin anlatılmaya başlandığı ve bittiği yer, tesadüfî değildir. Çünkü mekân, Ömer'in artık halk arasında bir efsaneye dönüşmüş olan acıklı hikâyesinin de son bulduğu yani küçük çocuğun intihar ettiği yerdir. Yolda kılavuzluk eden ihtiyar adam ile anlatıcı yabancı adamın yolculuğu kurgunun ilk halkası iken, Ömer'in asıl hikâyesi bunun altında yer alan ikinci halkada verilir. Her iki hikâye halkası da aynı anda ve Ömer'in ölümüyle son bulur. Söğütçük, Ömer'in kaybolduğu yerdir, denilerek anlatım sonlandırılır. Ömer' in sonunun "kaybolmak" fiiliyle anlatımı önemlidir. Çünkü “ölmek” fiili belirgin ve kesin bir sonu ifade ederken "kaybolmak" gizemli ve bilinmez bir durumu imlemektedir.

\section{Yakın toplumsal çevre}

İlhan Başgöz'ün halk hikâyelerini inceleme yönteminden yola çıkarak bir iletişim modeli ve aynı zamanda bir inceleme yöntemi sunan Serdar Öztürk'ün bu çalışma için de temel yol gösterici olarak seçilen makalesinde yakın toplumsal çevre, Başgöz'e göre halk hikâyesinin dinleyicileridir. Bă̆rıyanık Ömer adlı roman özelinde yakın toplumsal çevre nedir sorusunun yanıtı ise biraz farklıdır. Kurgu ve anlatım tekniği açısından başka bir yazılı metin için yakın toplumsal çevrenin dinleyiciye karşılık olarak okur olduğunu söylemek doğrudur. Oysa roman türündeki bir metni, bir halk hikâyesinin ikinci bir parçası olarak veren Bă̆rıyanık 
Ömer'de yakın çevre; okur ile birlikte romanın ilk bölümünde yer alan ve Ömer'in destana dönüşen kısacık hayatına ilişkin bilgileri paylaşan kişi ve roman kurgusundaki Söğütçük'ün halkıdır. Söğütçük'e bir vesile ile giden yabancının (ilk bölümün anlatıcısının) Ömer'in başından geçen üzücü olaylar hakkında bilgi vermek istediği anlaşılmaktadır. Bir adı olmayan bu kişi, birinci tekil kişili anlatım ile okurun karşısına çıkar. Birinci tekil kişi anlatımı, "bir zamanlar, vaktiyle bir köy, bir çocuk varmış", vb. masalsı, gerçek dışı bir anlatıdan okuru uzaklaştırdığı gibi olayların bizzat duyulduğuna, ana kaynaktan bizzat dinlenildiğine yani inandırıcılığına vurgu yapar. Burada altı çizilmesi gereken bir başka nokta ise, romanda Ömer'in hikâyesinin bilenler, anlatıyı dinleyenler üzerinde yarattığı etkinin de açıklanmış olmasıdır. Yani yukarıda belirtildiği gibi her yeni gelin ve güveyin kasaba yolundan geçerken, Söğütçük görünüp de gözden kayboluncaya kadar ona arkalarını dönmemeleri; başından iki nikâh geçmiş olan kadın ve erkeklerin Söğütçük'e uğramayıp Kızılpınar'dan su içmemeleri; bu durumda olanların kasaba yolundan başlarını eğerek ve Söğütçük'e bakmadan geçmeleridir. Yine bahtsız insanların buraya gelip sögütten kırk bir yaprak koparıp suya atmaları, böylece suyun onların dileklerini Allah'a götürdüğüne inanmalarıdır. Ömer'in hikâyesinin anlatımın yapıldığı sırada dinleyicide bıraktığı etkiyi Bağrlyanık Ömer adlı eser yazılı bir metin olduğu için söylemek olası değildir. Ancak, Ömer'in hikâyesini bilenler ve dinleyenler üzerinde yarattığı etkinin, başka bir deyişle anlatının kültürel işlevinin yerine geldiği anlaşılmaktadır. Ayrıca Söğ̈̈tçük ve Kızılpınar'ın Ömer'in kısacık yaşamı ile özdeşleşen hikâyesinin vermek istediği ana ileti (bencil ebeveynlerin çocuklarına zarar verdikleri) göz önüne alındığında, trajik sonun dinleyicilerin tepkileri ile değişmesi pek de olası görünmemektedir.

\section{Uzak toplumsal çevre: Politik rejim, medya, mekân, zaman}

Bağrıyanık Ömer adlı eserin uzak toplumsal çevre noktasında değerlendirebilmek için öncellikle romanın zaman kavramını doğru belirlemek gerekmektedir. Yazılı bir metin olan Bağrıyanık Ömer için üç farklı zamandan söz etmek gerekir: Eserin yazılma zamanı, eserde anlatma zamanı ve eserde vaka zamanı. Bă̆rıyanık Ömer' in ilk yayımlanma tarihi 1930 yılıdır. Araştırmacı Cihangir Doğan'a göre Türkiye'nin nüfusu 1930'dan 1990'a kadar yaklaşık 4 kat artmış ve boşanmaların da aynı dönemde 12 kat arttığı görülmüştür. Boşanmalardaki bu artış rakam olarak 1992'de 27.133'e ulaşmıştır (Doğan, 1998). Araştırmacılar Aydın ve Baran'a göre ise sanayi devrimi sonucu yaşanan toplumsal değişme, feodal döneme özgü tüm yapılarda farklılaşmayı da beraberinde getirmiştir. Evlenme ve boşanma olguları da bu değişim sürecinden etkilenmiş, sanayi devrimi sonrası modern topluma özgü yeni durumlar ortaya çıkmıştır. Sanayi devrimi sonrası yaşanan modernleşme ile birlikte evlilik katı kurallara bağlı olmaktan kurtulmuştur. Geleneksel yaşamda birçok soruna rağmen; çocuğun varlığı, dini ve örfi kuralların etkisiyle sürdürülen evliliklerin yerini modern yaşamda psikososyal doyumun her an yaşanmak istendiği evlilikler almaya başlamaktadır. Beklentilerin karşılanmadığı noktada ise boşanma artan oranları sonucunda daha fazla kişiyi ve çocuğu etkilemesiyle toplumsal boyutları aşıp evrensel bir sorun haline gelmektedir (Aydın ve Baran, 2010: s.117, 118). Türkiye'de evlilik ve aile kurumunun durumuna ilişkin farklı bilim disiplinlerince yapılmış çok sayıda araştırma bulunmaktadır. Çalışmanın sınırlılıkları dikkate alınarak burada bu araştırmalara ve sonuçlarına ayrıntılı biçimde değinilememiştir. Ancak toplumsal 
değişmelerin aile kurumunu etkilediği ve özellikle 1930'lardan itibaren Türkiye'de boşanmaların önemli bir olgu olarak toplum yaşamında yer etmeye başladığı söylenebilir. Parçalanmış bir aile içinde yalnız ve bakımsız kalmış bir çocuk olan Ömer'in hikâyesi ile yazar, anne ve babaların bencil, anlayışsız davranışlarının çocuklarına ne ölçüde zarar verdiğinin altını çizmekte; bir anlamda anlatı, önemli bir sorun üzerine toplumun dikkatini çekmektedir.

Romanın kurgusu içinde zaman unsurunun nasıl yer aldığına bakıldığında anlatma zamanı ile vaka zamanının farklı olduğu görülmektedir. Anlatma zamanı yıl olarak belli olmadığı gibi metinde buna dair fikir verebilecek herhangi bir ipucuna da rastlanmamaktadır. Romanın birinci tekil kişili anlatıcı ile anlatılan ilk kısmında zamana dair tek bilgi, çok sıcak bir yaz günü olduğudur. Sıcak bir yaz günü ise, romanın kurgusu içinde önemli bir işleve sahiptir. Ömer'in hazin hikâyesinin anlatılması, küçük çocuğun içine düştüğü duruma empati yapılabilmesi için sıcak bir yaz günü önemli bir zaman dilimidir. Romanın bu ilk kısmının anlatıcısı sıcak güneşin altında çok susar ve bir su kaynağına bir an evvel ulaşmayı ister. İşte sıcağın ve susuzluğun yarattığı sıkıntı ile anlatıcı ve ona kılavuzluk eden köylünün vardığı su kaynağının efsanesi önemli bir hâle gelir. Çünkü burada insanı susuzluktan perişan eden çok sıcak hava, romanın ikinci bölümünde anlatılan Ömer'in hikâyesinin can alıcı noktası ile de ilgi kurar. Anne babası tarafından bakılmayan, en çok sevdiği bu iki insandan hak ettiği sevgi ve ilgiyi göremeyen Ömer, aç ve susuz olduğu halde kendini uçurumdan aşağı atmıştır. Bu nedenle reel bir zaman tanımından çok kurguda susuzluğun yarattığı çaresizliğin altını çizen kuraklık ve sıcaklık hâli daha büyük önem taşımaktadır. Böylece aslında hikâyede anlatılan olaylar, zaman ve mekân açısından genişleyerek belirli bir coğrafyanın anlatısı olmaktan sıyrılıp daha evrensel bir anlatıya dönüşür. Dünyanın herhangi bir yerinde parçalanmış, dağılmış bir aile içinde bir çocuk, birtakım mağduriyetler yaşayabilir. Bă̆rıyanık Ömer' de küçük çocuğun aç susuz, bakımsız kalmış olması, aile içinde çocuğun hem anne hem de babası tarafından ezilmesinin metaforudur. Ömer anne ve babasının ilgisizliği, üvey anne ve babasının kötü davranışları ve derinden duyumsadığı yalnızlık, kimsesizlik duygusunun etkisiyle intihar etmiştir. 6 yaşlarında bir çocuğun intihar gibi bir yola başvurması, son derece uç bir görüntüdür. Ancak, yanlış bir tutumu eleştirmek ve yapılan hataların büyük sonuçlar doğurabileceğini göstermek adına anlatının Ömer'in yaşını da aşan, oldukça radikal bir davranışıyla son bulması, topluma yapılan bir uyarı olarak algılanmalıdır.

Romanın vaka zamanına gelince, metinde ikinci ve aslında asıl vaka zincirini oluşturan kısımdan hemen önce, Ömer'in hikâyesini anlatan aksakallı ihtiyarın anlatımına, “-Yüzlerce yıl evveldi. Geçtiğin ovada bir şehir kuruluydu. (...)” (Yesari, 2017: s.19) eklindeki sözlerine yer verilir. Dolayısıyla Ömer'in başından geçenlerin anlatma zamanından yüzlerce yıl önce gerçekleştiği bilgisi verilerek vaka zamanına işaret edilir. Romanın Ömer' in hikâyesinin anlatıldığı bu ikinci bölümünde Ömer'in babası Bakır Efe ile annesi Emine'nin boşanmak üzere kadıya gitmeleri (Yesari, 2017: s. 55, 56) önemli bir işleve sahiptir. Kadı tarafından boşanma $^{2}$, bir anlamda zaman olarak birkaç yüzyıl yıl öncesini doğrularken diğer yanda yaşanı-lanların masal değil, gerçek olduğuna vurgu yapar. Aslında edebî tür olarak romanın anlattığı olaylar ya da durumların kendisinin gerçekliği konusunda okuru inandırmaya çalışmak gibi bir görevi bulunmamaktadır. Çünkü buna gerek yoktur. Roman tür olarak, gerçekte yaşanmış ya da yaşanması olası olay ve durumların anlatımı biçiminde tanımlanır. Mahmut Yesari de Bağrıyanık Ömer'i ilk bölümü atarak sadece ikinci bölümden oluşan bir metin olarak kale- 
me alabilirdi. Bu durumda, metin sadece roman türünün bir örneği olurdu. Oysa Ömer'in hikâyesinin başına eklenen küçük bölüm ile sonunda yer alan iki kısa paragraf, eseri bütünsel anlamda bir romandan çok bir efsanenin modernize edilmiş anlatımına dönüştürmüştür. $\mathrm{Bu}$ da küçük bir çocuğun içinde bulunduğu açmaza çözüm olarak intihar gibi çok radikal bir yola yönelmesinin gerçeklik olgusuna ne ölçüde yaklaştığını tartışmaktan uzaklaştırmıştır. Ayrıca, ebeveynlerin çocuklarına verdikleri zararları ve bunların ağır sonuçlarını, Ömer'in öldüğü yerde oluşan doğal bir güzellik ile hem yumuşatmış hem de kalıcılığına (o bölgeden geçerken insanların gösterdiği davranış kalıplarına) dikkat çekmiştir.

Sosyal gösterimin uzak toplumsal çevre iletişimi içinde medya ayağı da bulunmaktadır. Ancak sosyal psikoloji açısından medya ve metin ilişkisinde aslında toplum tarafından görünmeyen, bilinmeyen bir nesne, ürün ve benzerinin bilinir kılınması amacı vardır. Bu bağlamda edebî metinlerin sinema veya televizyon dizilerine uyarlamalarıyla toplumun bu metinlerden haberdar olduğu söylenebilir. Türk ve dünya edebiyatından pek çok edebî eser, medya aracılığıyla bilinir olmuştur. Băgrıyanık Ömer adında 1980 yapımı, yönetmenliğini Yücel Uçanoğlu'nun yaptığı ve başrolünü Müslüm Gürses’ in oynadığı bir film vardır. Ancak balıkçılık yaparak geçimini sağlayan fakir bir gencin başından geçenlerin anlatıldığı bu filmin roman ile tek benzerliği adıdır.

\section{Sonuç}

Anlatım tekniği ve kurgu açısından Bağrıyanık Ömer, bir halk hikâyesinin yazıya aktarımı görüntüsü çizmektedir. İki parçalı kurgunun ilk bölümündeki anlatıcı kahraman, Ömer'in yazıya aktarılmış, kısacık yaşam hikâyesini aksakallı bir masal anlatıcısının okuduğu metinden dinlediğini söyler. Böylece yazıya geçirilmiş bir halk hikâyesinin varlığı gündeme gelir. Romanın yine en başında ilk anlatıcıya yolda kılavuzluk eden ihtiyar adam tarafından Anadolu'nun birçok yerleşim yerine verilen Ömerli adına, küçük bir çocuk olan Ömer'in başından geçenlerin ve trajik sonunun kaynaklık ettiğinin söylenmesi, efsane türüne özgü bir yapı kullanımıdır. Ömer'in hikâyesi ya da daha doğru söylemle Söğütçük/Kızılpınar'ın efsanesinin oluşumu ve dile getiriliş biçimi; kavuşamayan âşıkların acıklı hikâyelerinden, töreye karşı gelip dinî ve ahlakî değerlerin dışına çıkan hareketlerin gerçekleşmesi sonucu yüz yüze gelinen yaptırımlardan veya cinlerden, albastı ve benzeri durumlardan korunmayı sağlayan ritüellerin anlatımından farklıdır. Băgrıyanık Ömer'de görülen durum, halk hikâyesi ile efsanenin içerik ve biçim açısından kendini modernize etmesidir. Roman boşanmanın/ailenin parçalanmasının çocuklar üzerindeki olumsuz etkilerini konu edinip toplumsal bir olguya örtülü biçimde dikkat çekmektedir. Romanda açık bir biçimde boşanma kötüdür, ebeveynler çocukları için fedakârlık yapmalıdır gibi bir ileti yoktur. Ancak romanın ana iletisi, ebeveynlerin bencil olmamaları gerektiği, kendilerine yeni aile kurmaları durumunda ilk evliliklerinden olan çocuklarını ihmal etmemeleri gerektiğidir. Romanın yayımlandığı 1930'lu yılların Türkiye'de boşanma eğiliminin arttığı bir zaman olması, yazarın boşanmayı normal, çocuğun ilgisiz ve sevgisiz kalışını ise yanlış bulduğunu göstermektedir. Yazar, romanında çocuk kahramanı Ömer'i intihar ettirerek ailelere uyarıda bulunmaktadır. Băgrıyanık Ömer adlı roman, bir halk hikâyesinin insanları ve toplumu yanlış yapmaktan koruma ve onlara uyarıcı bir güç olma işlevini koruyarak, kendisini modern ve yazılı bir anlatım türü içinde yeniden yorumlamasıdır. 


\section{Notlar}

1 Romanda özellikle şarkı sözcüğünün kullanıldığı görülür. Bu bölümde anlatıcı şöyle der: “İhtiyar köylü, hem yürüyor, hem titrek bir sesle, bir köy havası tutturmuş gidiyordu bu hava ne kayabaşl, ne mâniye, ne kesikkereme benziyordu. Her nağmesinde esrarlı bir titreyiş, uçuş, kanatlanış vardı. Bir destana da benzeyen bu şarkının esrarlı havasını, iliklerimi sarmış, kalbim burkula burkula, içimde ı̆̆ıltılarla dinliyordum. " (Yesari, 2017, s. 14)

2 Saadet Maydaer, "Klasik Dönem Osmanlı Toplumunda Boşanma (Bursa Şer’iyye Sicillerine Göre)" başlıklı makalesinde "Erkeğin tek tarafl iradesiyle karısından boşandığını yalnızca söz ile bildirmesi dahi yeterli görülmüş̧ür. Durumu mahkemeye kaydettirmesi hukuken şart koşulmamıştır. Fakat mahkeme sicillerinde karşımıza çıkan çok sayıda boşanma belgesi, Osmanlı toplumunda boşanmaların kayda geçirildiğini göstermektedir." (Maydaer, 2007, s.300,301) demektedir.

\section{Kaynaklar}

Alemdar, K.; Kaya, R. (1983). Kitle iletişiminde temel yaklaşımlar. Ankara: Savaş.

Alemdar, K.; Erdoğan, İ. (1994). Popüler kültür ve iletişim. Ankara: Ümit.

Arkonaç, S. A. (2001). Sosyal psikoloji (genişletilmiş 2. baskl). İstanbul: Alfa.

Başgöz, İ. (1998). Sözlü anlatım türlerinde konudan sapmalar (digresyon). folklor/edebiyat İlhan Başgöz Özel Sayısı. Cilt: III. Sayı: 14. s.99-112.

Debord, G. (2006). Gösteri toplumu ve yorumlar (2. basım). (A. Ekmekçi, O. Taşkent, Çev.). İstanbul: Ayrint1.

Doubtfire, D. (1999). İnsanlarla iyi geçinmenin yöntemleri (3. Baskl). İstanbul. Rota.

McQuail, D.; Windhal, S. (1997). Kitle iletişim modelleri. (K. Kumlu, Çev.) Ankara: İmge.

Yesari, M. (2017). Bağriyanık Ömer. İstanbul: Özgür.

\section{Elektronik kaynaklar}

Aydın, O.; Baran, G. (Ekim 2010). Toplumsal değişme sürecinde evlenme ve boşanma. Toplum ve Sosyal Hizmet. Cilt: 21. Say1: 2. s. 117-126. (http://www.acarindex.com/dosyalar/makale/acarindex-1423931266.pdf) (E.T.: 19.04.2019)

Doğan, C. (1998). Türkiye'de boşanma sorununun sosyolojik ve istatistiki açıdan değerlendirilmesi. Sosyoloji Konferansları. Cilt: 0. Say1: 25. sf. 59-69. (http://dergipark.gov.tr/iusoskon/issue/9525/119014. E.T. 04.04.2019)

Maydaer, S. (2007). Klasik dönem Osmanlı toplumunda boşanma (Bursa Şer'iyye Sicillerine Göre). T.C. Uludağ Üniversitesi İlahiyat Fakültesi Dergisi. Cilt: 16, Sayı: 1, s. 299-320. (http://dergipark. gov.tr/download/article-file/143797 E.T. 5.04.2019)

Moscovici, S. (1984). The Phenomenon of social representations. In R.M. Farr \& S. Moscovici (Eds.), Social Representations. Cambridge: Cambridge Press. / Moscovici, S. (1988). Notes tovvards a description of social representations. European Journal of Social Psychology, 18, 211-250.

Öner, B. (2002). Sosyal temsiller. Kriz Dergisi. Cilt: 10. Say1: 1. s. 29-35. (http://dergipark.gov.tr/kriz/ issue/41084/496543 E.T. 06.4.2019)

Öztürk, S. (2006).İletişim bilimi ile halkbilimi buluşturan bir bilim insanı: İlhan Başgöz. Folklor/Edebiyat. Cilt: 12, Say1 :48, s. 45-59. [https://www.academia.edu/36831267/\%C4\%B0LET\%C4\%B0 $\% \mathrm{C} 5 \% 9 \mathrm{E} \% \mathrm{C} 4 \% \mathrm{~B} 0 \mathrm{M} \_\mathrm{B} \% \mathrm{C} 4 \% \mathrm{~B} 0 \mathrm{~L} \% \mathrm{C} 4 \% \mathrm{~B} 0 \mathrm{M} \% \mathrm{C} 4 \% \mathrm{~B} 0 \_\% \mathrm{C} 4 \% \mathrm{~B} 0 \mathrm{LE} \_\mathrm{HALKB} \% \mathrm{C} 4 \% \mathrm{~B} 0 \mathrm{~L} \% \mathrm{C}$ 4\%B0M\%C4\%B0N\%C4\%B0_BULU\%C5\%9ETURAN_B\%C4\%B0R_B\%C4\%B0L\%C4\%B0M _\%C4\%B0NSANI_\%C4\%B0LHAN_BA\%C5\%9EG\%C3\%96Z (E.T. 04.04.2019)] 